\title{
施設栽培ピーマンに扔けるミナミキイロアザミウマ の総合防除法
}

\author{
金城 常雄・仲宗根 徹・新崎 正信 ${ }^{11}$-長嶺 由範 ${ }^{21} \cdot$ 鈴木 寛 $^{3)} \cdot$ 宮良 安正 ${ }^{31}$ \\ (沖縄県南部病害虫防除所・11)沖縄県中部農業改良普及所・2)沖縄県農業試験場園芸支場・31沖縄県農業試験場)
}

\begin{abstract}
Integrated control of Thrips palmi on green pepper cultivated in a greenhouse. Tuneo KINJO, Toru NAKASONE, Masanobu ARASAKI ${ }^{1 \text {, }}$, Yosinori NAGAmINE ${ }^{2)}$, Hiroshi SUZUKI ${ }^{3)}$ and Ansei MiYara ${ }^{3)}$ (Okinawa Prefectural South Plant Pro. tection Office, Naha, Okinawa 903. ${ }^{1}$ Okinawa Prefectural Middle Agricultural Extention Station, Gushikawa, 904-22. ${ }^{2}$ Horticultural Branch, Okinawa Prefectural Agricultural Experiment Station, Gushikawa, Okinawa 904-22. ${ }^{3}$ Okinawa Prefectural Agricultural Experiment Station, Naha, Okinawa 903)
\end{abstract}

\section{緒言}

ミナミキイロアザミウマ(Thrips palmi KARNY) は, 九 州, 四国, 本州の野菜生産地帯を中心に24都府県で猛威 をふるっている難防除害虫である。沖縄県においても， 1981年以降発生面積が增加し, 冬春季に㧍ける県外出荷 用の施設栽培及び夏秋季に扔ける露地栽培野菜に大被害 を与えている。また，本種は直接的被害を与えるばかり ではなく、スイカの灰白色斑紋病（TSWVの新しい系 統）の媒介者としての役割を果していることから，ウイ ルス予防を前提とした防除体系の確立が切望されている。 筆者らは, 病害虫防除紷合対策事業の一環として, 近 紫外線除去フィルム及び銀色寒冷紗などの農業用被覆資 材による物理的防除法の実証展示直場を主要産地に設け， その効果を調查した。また近紫外線除去フィルム被覆条 件下でのピーマンの生育・収量調查及び県外出荷用の蒸 熱処理による果色への影響を調査した。さらに逐次抽出 法による要防除密度の查定も試みたので報告する。本文 に先だち，多大な御指導を賜った沖縄総合事務局今村哲 夫植物防疫係長及び読谷村役場経済課玉城悟氏に厚くお 礼申し上げる。

\section{材料及び方法}

\section{1. 読谷村における実証展示粗場}

1982年9月27日に，沖縄県読谷村渡慶次の連棟鉄骨八 ウス $\left(800 \mathrm{~m}^{2}\right)$ においてピーマン（品種“エース”）苗を 畧巾 $160 \mathrm{~cm}$ 株間 $60 \mathrm{~cm} の 2$ 条植え，外張り被覆処理までの 間白色寒冷秒を用いたトンネル栽培を行った。同年11月 9 日に, 各八ウスの屋根を近紫外線除去フィルム（改良 区）及び農業用酢酸ビニル（慣行区）により外張り被覆
した。なお，両区とも八ウス側面を白色寒冷紗により被 覆し, 黒色ポリフィルムで土壤表面を覆った。調查方法 としては，ハウス中央部に白色円筒粘着トラップを2 個 ずつ地上高 $80 \mathrm{~cm} に$ 設置し, 誘殺成虫数を調べた。また, 花上の生息密度は，ハウス内の 1500 株中から 1 列当り 5 株を 2 列おきに 6 列抽出し, 計 30 株の開花後 $1 \sim 2$ 日目 頃の各々 2 花ずつ(総60花)を調查した。さらに, 花上 の生息密度と同し抽出法により収穫果実（総60果）につ いて以下に示したグレード別の被害果数を調查し，それ らから出荷率及び秀品率を算出した。
$\mathrm{A}$ ：健全果。B：へ夕部の被害が散見される。
C：ヘタ及び果皮部での被害が散見される。
$\mathrm{D}$ :ヘタ及び果皮部での被害が著しいもの。
出荷率 $=(\mathrm{A}$ 及び $\mathrm{B}$ 級の果数 $/ 60) \times 100$
秀品率 $=(\mathrm{A}$ 級の果数 $/ 60) \times 100$

各調查は, ほほ 1 週間ごとに行った。なお, 両区とも 本種を対象とした薬剤散布は10回実施された。

1983年 9 月 29 日に, 読谷村渡慶次の連棟鉄骨ハウス $\left(800 \mathrm{~m}^{2}\right)$ においてピーマン(品種“エース”) 苗を畧巾 $160 \mathrm{~cm}$ 株間 $60 \mathrm{~cm}$ の 2 条植えし, シルバーストライブフィ ルムによる土壤面被覆及び銀色寒冷紗を用いたトンネル 被覆を施した。その後11月3日に各ハウス全面を近紫外 線除去フィルム (改良区) 及び農業用酢酸ビニル（慣行 区）により外張り被覆した。なお，画区ともハウス側面 及び入口部を銀色寒冷紗により被覆した。さらに慣行区 のみ白・水色ストライプ粘着トラップ(パルミトール゙) を $3.3 \mathrm{~m}^{2}$ 当り 1 本ずつ設置し大量誘殺法を適用した。調 査方法は, 前年度の調査基準に準じた。

2. 近紫外線除去フィルム被覆条件下におけるピーマン 


\section{の生育・収量及び果色調查}

沖縄県園芸支場（具志川市兼ヶ段）のパイプハウス $\left(80 \mathrm{~m}^{2}\right)$ 内に 1 区 $5 \mathrm{~m}^{2} 2$ 反覆の試験区を設け，1983年10 月18日にピーマン (品種“エース”) 苗を畧巾 $180 \mathrm{~cm}$ 株間 $50 \mathrm{~cm}$ の 2 条植えした。外張り資材として，近紫外線除去 フィルム及び塩化ビニルを用い，各ハウスを11月 8 日に 被覆した。両区とも八ウス側面は銀色寒冷紗で被覆し， 黒色ポリフィルムで土壤表面を覆った。施肥量は $10 \mathrm{a}$ 当 り $\mathrm{N}-61 \mathrm{~kg}, \mathrm{P}-53 \mathrm{~kg}, \mathrm{~K}-59 \mathrm{~kg} て ゙ 60 \%$ を基肥に残り $40 \%$ を 5 回に分けて追肥した。また，薬剤散布は両区とも， BPMC 乳剂及び DMTP 水和剤をほほ7日おきに散布し た。調查方法としては，ほほ7日おき，各区50花ずつ 任意に抽出し，花上の成虫数を数えた。また，生育初期 （10月18日）に草丈及び茎長を，生育中期（3月 6 日） 及び後期（6月 5 日）に節間，莱柄長を測定した。さら に，収穫果実の果色調査としては，色彩色差計（ミノル 夕製 CR-100) により，蒸熱処理前及び後の $\mathrm{L}^{*}, \mathrm{a}^{*}, \mathrm{~b}^{*}$ (CIE 1976色空間) 值を測定し色差 $(\Delta \mathrm{E})$ を算出した。 また, 蒸熱処理前後, 1 日目及び 6 日目の計 4 回生重量 を測定し室温条件で目減率を求めた。

\section{3. 逐次抽出法による要防除密度の推定}

1984年 4 月 9 日から16日にかけて，沖縄本島の一般施 設ピーマン煵場を計8 8 力所を任意に抽出し，各ハウスご とに30株ずつ任意に抽出し，株当り2花ずっ（計60花） の成虫数を調查した。これらより IWAO (1968)の平均密 度と平均こみ合い度との関係に基つくく空間分布の特性を 推定し，またKUNO (1969）及び IWAO (1975) による一定 の相対精度の密度推定法と逐次抽出法による防除要否の 判定法を検討した。

さらに，1985年 1 年から 4 月にかけて各月中旬に沖䋥 本島内を巡回調查し，農業用被覆資材の利用状況及び各 ハウスの60花当りの成虫数（標本抽出法は，空間分布の 特性の際に準ずる）を調查した。

結果

\section{1. 読谷村における実証展示围場}

第 1 困に，1982年加 1983年に読谷村の実証展示甬場 で行った，近紫外線除去フィルム被覆ハウス及び農業用 酢酸ビニル被覆ハウスの白色粘着トラップへの誘殺成虫 数及び60花当りの成虫数調查の結果を示した。

農業用酢酸ビニル被覆八ウス（慣行区）における60花 当り成虫数は，11月中旬から 4 月上旬にかけて 100 頭前 後で推移し，その後300頭に達した。一方，近紫外線除 去フィルム被覆八ウスでは，11月から1月にかけて5 頭 前後で推移し，その後，指数的に增加したものの150頭

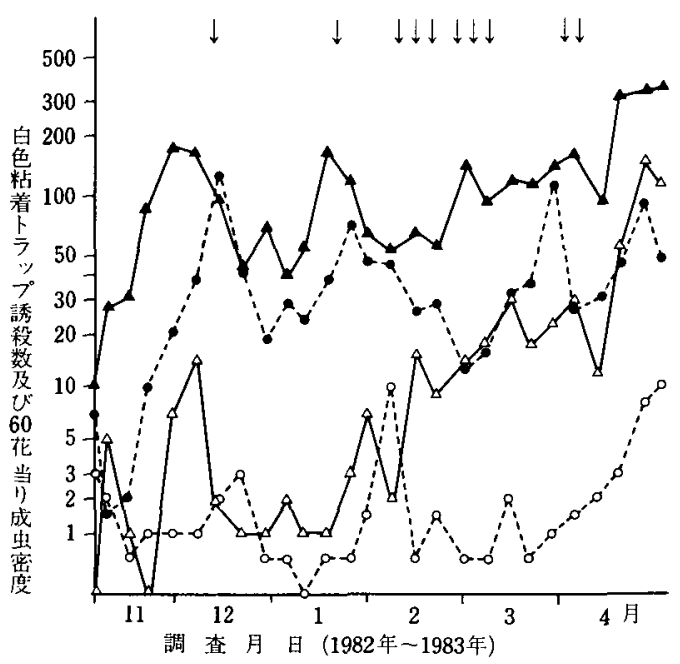

第1図読谷村の近紫外線除去フィルム実証展示直場に おけるミナミキイロアザミウマの発生消長（昭 和 57 年度)

黒丸点線は農業用酢酸ビニルフィルム（慣行）区の白色 粘着トラップ誘殺数（週当り）。黑三角実線は慣行区の60 花当り成虫密度。白丸点線は近紫外線除去フィルム(改良) 区の白色トラッフ誘殺数（週当り）。白三角点線は改良区 の60花当りの成虫密度。矢印は薬剂散布日。

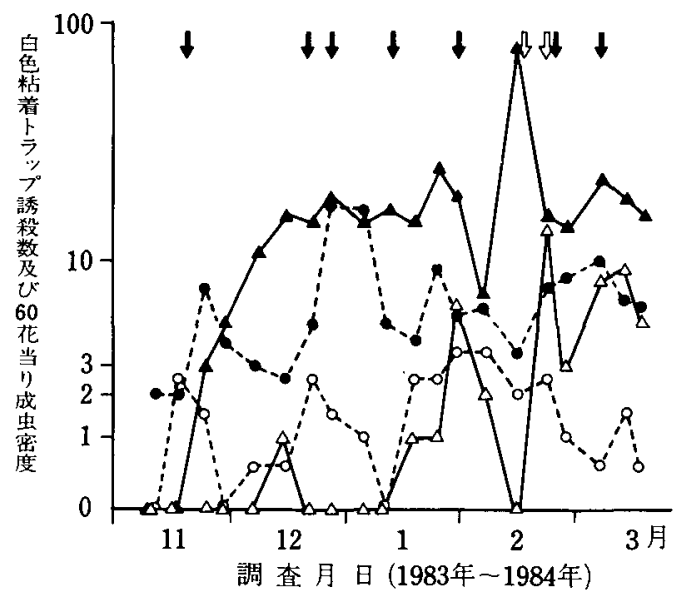

第 2 図読谷村の近紫外線除去フィルム実証展示阑場に おけるミナミキイロアザミウマの発生消長（昭 和 58 年度)

黑丸点線は農業用酶酸ビニルフィルム（慣行）区の白色 粘着トラップ誘殺数（週当り）。黑三角実線は慣行区の60 花当り成虫密度。白丸点線は近紫外線除去フィルム (改良) 区の白色トラッフ誘殺数（週当り）。白三角点線は改良区 の60花当りの成虫密度。黑矩印は慣行区の菜剂散布日， 白矢印は改良区の薬剂散布日。

前後の発生量に留まった。また，白色粘着トラップへの 誘殺数についても同様の傾向が認められた。

第 2 図には，1983年から1984年にかけて行った同様の 
調查結果を示した。農業用酢酸ビニル被覆ハウスにおけ る60花当り成虫数は，11月中旬から 12 月中旬にかけて指 数的に増加したものの 1 月以降20頭前後で推移した。近 紫外線除去フィルム被覆八ウスに扔ける60花当り成虫数 は，11月から1月上旬にかけてほほ０であった。1月中 旬以降增加したものの約10頭前後の発生に留まった。な お，薬片散布回数は，農業用酢酸ビニル区では 7 回に対 して, 近紫外線除去フィルム区では 2 回に留まった。

第 3 図には，1982年～83年及び1983年～84年の60花当

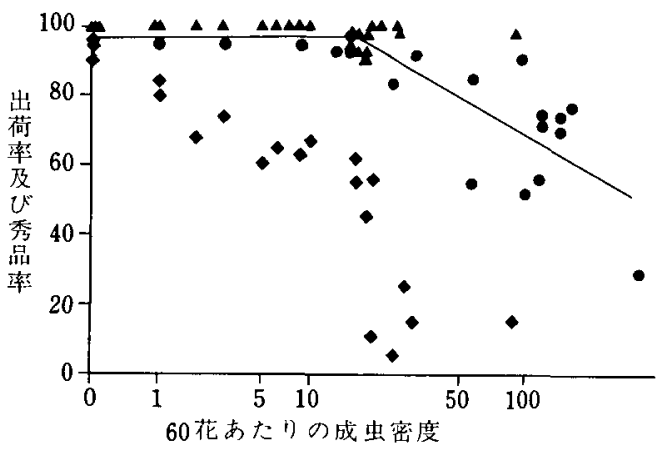

第 3 図 60花当りの成虫密度とピーマン果実の出荷率及 び秀品率との関係

丸印が昭和57年度の出荷率, 三角印は昭和58年度の出荷

率，四角印は昭和 58 年度の秀品率を表わした。

りの成虫密度に対するピーマン果実の出荷率を示した。 ます 60 花当り 15 頭末満の成虫密度は少なくとも $90 \%$ 以上 は出荷が可能であるが，15頭以上では密度依存的に出荷 率が低下した。また，2 年目の秀品率においては，出荷 率に比べ低密度から密度依存的に低下傾向を示したもの の60花当り15頭未満では50\%以下には落ち込まなかった。

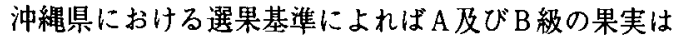
県外出荷用，C級品は県内消費に回されるため，秀品率 よりも出荷率の方が農業経営上の影響は大きい。以上の 理由により施設ピーマンにおける経済的被害許容水準を 60 花当り15頭と仮定した。

2. 近紫外線除去フィルム被覆ハウスにおけるビーマン の生育・収穫調查及び果色調査

第 4 図には, 近紫外線除去フィルム被覆ハウスでのミ ナミキイロアザミウマの100花当りの成虫密度を示した。

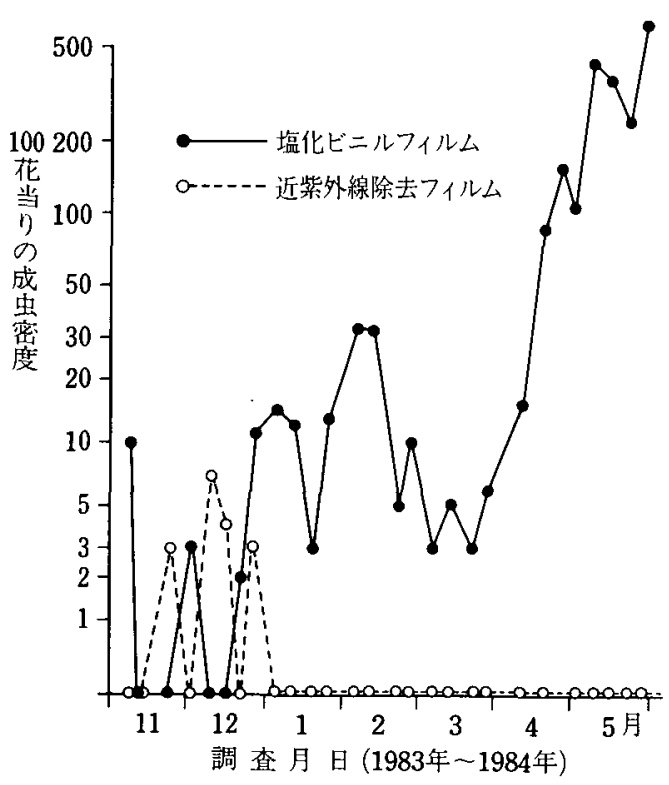

第 4 図 近紫外線除去フィルム被覆条件下のミナミキ1 ロアザミウマの発生消長

11月から12月にかけては両区とも5頭前後の発生量であ った。塩化ビニル区では 1 月から 2 月にかけて10頭前後 で推移し，3月以降指数関数的に急增し 5 月には 500 頭 に達しだ。一方，近紫外線除去フィルム区では，1月中 旬以降発生が認められなかった。第 1 表には,ピーマン の生育・収量を示した。収穫調查より近紫外線除去フィ ルム区では，総収量及び商品化率が約 $10 \%$ 増加した。ま た，本種による被害果率も塩化ビニル区では $56.3 \% に$ 達

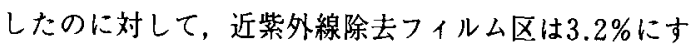
ぎず商品価值が著しく向上した。

沖綶県（久米島を除く）に拈いては，ウリミバエの本 土への侵入を防止するため，県外出荷用のピーマン果実 に対しては $43 \sim 43.8^{\circ} \mathrm{C} 3$ 時間の蒸熱処理が実施されてい る。第 2 表には, 蒸熱処理前後の両被覆資材使用ハウス における果色及び目減率を示した。各調査時期の塩化ビ ニル区に対する近紫外線除去フィルム区の色差は, 2.0 以下で，大部分の人々が色差に気付く閥值（ $\Delta \mathrm{E}=3.0 ）$ には達しなかった。また蒸熱処理による色差についても， 3月下旬の近紫外線除去フィルム区を除き上記した閾値

第 1 表 近紫外線除去フィルム被㠅によるピーマンの生青・収量及びミナミキイロアザミウマによる被害

\begin{tabular}{|c|c|c|c|c|c|c|c|c|c|c|c|}
\hline \multirow{2}{*}{$\begin{array}{l}\text { 供試外張り } \\
\text { 被覆資材 }\end{array}$} & \multicolumn{2}{|c|}{ 生 育 初 期 } & \multicolumn{3}{|c|}{ 生 育 中 期 } & \multirow{2}{*}{$\frac{\text { 生 }}{\text { 草丈 }}$} & \multirow{2}{*}{$\begin{array}{l}\text { 育 後 } \\
\text { 㨬 長 }\end{array}$} & \multirow{2}{*}{$\frac{\text { 期 }}{\text { 葉柄長 }}$} & \multirow{2}{*}{$\begin{array}{c}\text { 綌 収 量 } \\
(\mathrm{kg} / \mathrm{a})\end{array}$} & \multirow{2}{*}{$\begin{array}{l}\text { 商品 化 } \\
\text { 收量 }(\mathrm{kg} / \mathrm{a})\end{array}$} & \multirow{2}{*}{$\begin{array}{l}\text { 被害 } \\
\text { 果率 }\end{array}$} \\
\hline & 草丈 (cm) & 茎長 (cm) & 草丈 & 茎 長 & 葉柄長 $(\mathrm{cm})$ & & & & & & \\
\hline 塩化 $ヒ=ル$ & 37.7 & 29.3 & 84.7 & 75.6 & 4.7 & 160.0 & 149.1 & 5.6 & 917.1 & 780.1 & 56.3 \\
\hline $\begin{array}{l}\text { 近紫外線 } \\
\text { 除去フイルム }\end{array}$ & 40.4 & 32.4 & 78.4 & 78.4 & 5.4 & 161.4 & 150.8 & 6.2 & 1043.4 & 908.3 & 2.2 \\
\hline
\end{tabular}


第 2 表 蒸熱処理によるピーマン果実の果色及び目減率への影響

\begin{tabular}{|c|c|c|c|c|c|c|c|c|c|c|c|c|c|c|}
\hline \multirow{2}{*}{$\begin{array}{l}\text { 供試外張 り } \\
\text { 柀覆資 材 }\end{array}$} & $\begin{array}{l}\text { 調 } \\
\text { 時 }\end{array}$ & \multicolumn{5}{|c|}{ 蒸熱 処 理 前 日 } & \multicolumn{5}{|c|}{ 蒸熱処 理後 1 日 目 } & \multicolumn{3}{|c|}{ 処理後目減率 } \\
\hline & 期 & $\mathrm{L}^{*}$ & $a^{*}$ & $b^{*}$ & $\Delta E_{1}^{2}$ & $\Delta \mathrm{E}_{2}{ }^{\mathrm{b}}$ & $\mathrm{L}^{*}$ & $a^{*}$ & $b^{*}$ & $\Delta \mathrm{E}_{1}^{\mathrm{a}}$ & $\Delta \mathrm{E}_{2}{ }^{\mathrm{b}}$ & 1 日目 & 3 日目 & 6 日目 \\
\hline \multirow{3}{*}{ 塩化ビニル区 } & 2 月下旬 & 37.1 & -8.3 & 8.6 & - & - & 35.5 & -8.6 & 9.6 & - & 1.9 & 96.1 & 91.7 & 89.9 \\
\hline & 3月下旬 & 35.2 & -9.2 & 9.8 & - & - & 35.0 & -8.2 & 8.2 & - & 1.9 & 99.2 & 95.7 & 92.8 \\
\hline & 4 月下旬 & 37.4 & -9.7 & 9.8 & - & - & 35.9 & -9.2 & 9.0 & - & 1.8 & 97.7 & 91.3 & 86.2 \\
\hline \multirow{3}{*}{$\begin{array}{l}\text { 近紫外線除去 } \\
\text { フィルム区 }\end{array}$} & 2 月下旬 & 36.2 & -7.4 & 7.4 & 1.7 & - & 34.2 & -8.0 & 8.2 & 2.0 & 2.2 & 95.1 & 91.3 & 88.5 \\
\hline & 3 月下旬 & 36.7 & -9.6 & 10.5 & 1.7 & - & 36.1 & -7.6 & 7.4 & 1.5 & 3.7 & 98.5 & 95.6 & 92.3 \\
\hline & 4月下旬 & 36.4 & -9.2 & 8.8 & 1.5 & - & 36.3 & -8.9 & 8.6 & 0.6 & 0.4 & 97.7 & 91.2 & 85.9 \\
\hline
\end{tabular}

$\Delta \mathrm{E}=\left[\left(\Delta \mathrm{L}^{*}\right)^{2}+\left(\Delta \mathrm{a}^{*}\right)^{2}+\left(\Delta \mathrm{b}^{*}\right)^{2}\right]^{1 / 2} \mathrm{a}: \Delta \mathrm{E}_{1}$ は各調查時期の塩化ピニル区に対する近紫外線除去フィルム区の 色差を示した。b： $\Delta \mathrm{E}_{2}$ は各外張り被覆資材区の蒸熱処理前日に対する処理後 1日目の色差を示した。

色差の程度は $\Delta \mathrm{E}^{092}$ 值が 0 0.5の場合：きわわてわずかに異なる $0.5 \sim 1.5$ の場合：わずかに異なる 1.5 ～3.0の場合：感知し得る程に異なる $3.0 \sim 6.0$ の場合：著しく異なる 6.0 - 12.0 の場合：きわめて著しく 異なる 12.0以上の場合：別の色系綍になると客観的に表わせる。

$(\Delta E=3.0)$ 以下の值を示した。なお 3 月下旬の近紫外 線除去フィルム区の果色は蒸熱処理により $\mathrm{a}^{*}$ 值が2.0 增加し、 b*值が3.1隇少したことから供試した果実中に 老化したものが混入したのが原因と考えられ，肉眼的に もつやなし果は認如れなかった。さらに, 蒸熱処理後 の目隇率についても；両区の差はほとんど認められなが った。

\section{3. 逐次抽出法による要防除密度の查定}

第 5 図に，本種の成虫の花あたり平均密度 $(\mathrm{m})$ と平 均こみ合い度（券の関係を示した。 $\mathrm{m}$ 青との間には (1) 式の直線関係が認められた。

$$
\stackrel{m}{m}=0.5617+1.0771 \mathrm{~m} \quad(\mathrm{r}=0.9862) \cdots \cdots(1)
$$

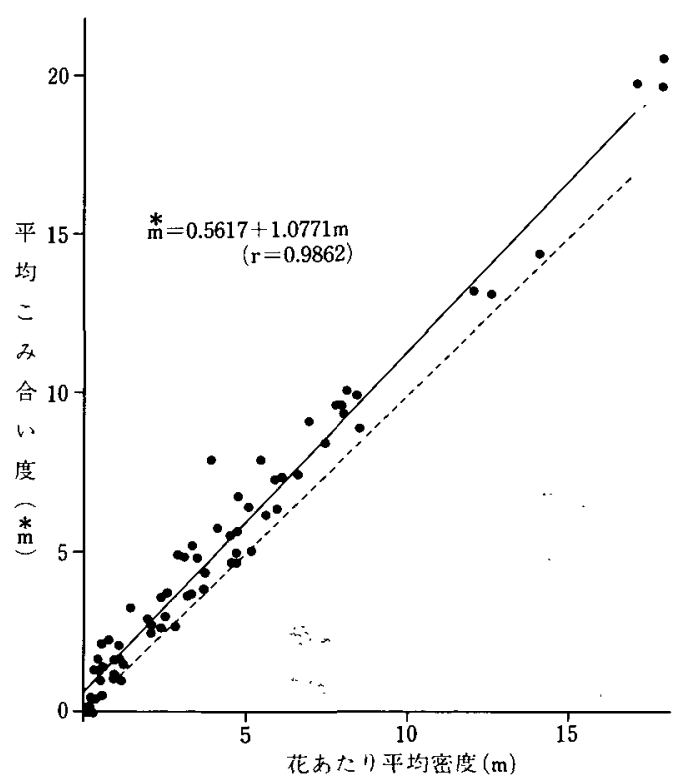

第 5 図施設栽培ピーマンにおけるミナミキイロアザミ ウマ成虫の花当りの平均密度 $(\mathrm{m})$ と平均こみ 合い度 $(\stackrel{*}{m})$ の関係

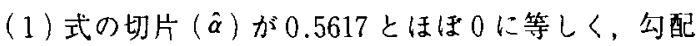
$(\hat{\beta})$ が1.0771とほほ1であることから，空間分布型は， ほぼ個体を単位とするランダム分布であることがわかっ

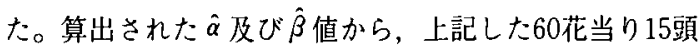
$(\mathrm{m}=0.25)$ を経済的被害許容水準とした場合の必要標 本花数と累積採集個体数の関係を第 6 図に示した。

第 6 図より，少なくとも累積採集個体数 (Tq) が10頭 及び18頭を越えれば，ほほ 0.4 及び0.3の相対精度で密度 推定が可能であり，特に相対精度が 0.4 の場合，60花当 り10頭以下であれば，経済的被害許容水準の下限線を越 えないので当面の防除は必要ないと考えられた。

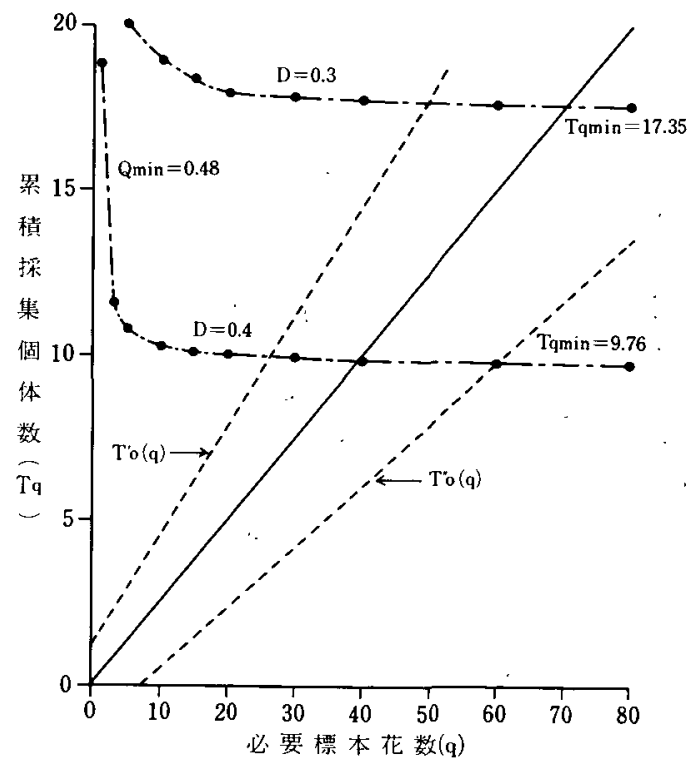

第 6 図逐次抽出法による要防除密度 $(\mathrm{m}=0.25)$ に基 づく防除要否ライン

黒丸一点斜線は相対精度 0.4 及び 0.3 場合の調査打ち切 ク曲線。点線が経済的被害許容水準 $(\mathrm{m}=0.25)$ の上限 及び下限線を示した。 
第 3 表 施設栽培ピーマンにおける農業用被覆資材の組み合わせ別の60花当りミナミキイロアザミウマの成虫数

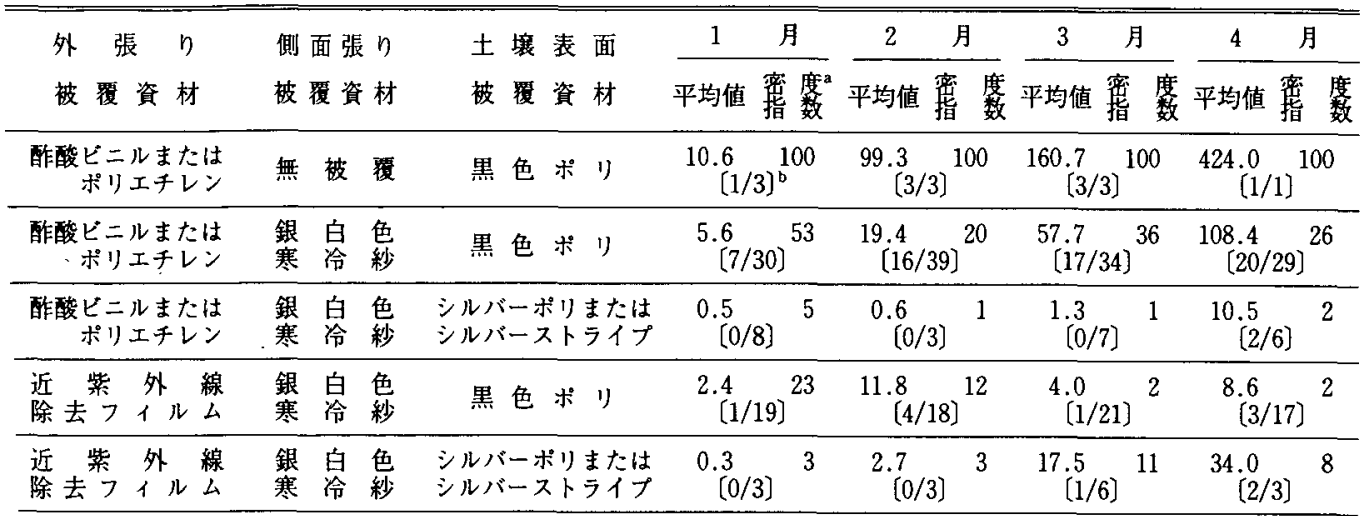

a : 密度指数は農業用酢酸ビニルもしくはポリエチレンフィルム十無被覆＋黑色ポリフィルム区の平均值を100とし た場合の各区の平均値の比率を示した。

$\mathrm{b}:[]$ [の数字の分母は各組み合わせの調查围場数, 分子は要防除密度に基づき防除が必要である围場数を示し た。

第 3 表には，各種の農業用被覆資材を組み合わせた一 般施設ピーマン栽培における60花当りの本種の平均成虫 数を示した。農業用酢酸ビニルもしくは塩化ビニルフィ ルム外張り被覆条件下において，銀色もしくは白色寒冷 秒により側面張り被覆した击場では，無被覆に比べ，各 月とも相対的に低密度で推移した。さらに, シルバーポ リ及びシルバーストライプフィルムの土壤表面被覆が併 用された围場では，無被覆区の約 $1 / 20$ 以下の発生量に抑 えた。

同じように銀色もしくは白色寒冷紗を併用した区でも， 近紫外線除去フィルム外張りハウスの方が, 農業用酢酸 ビニルもしくは塩化ビニルフィルムに比べ，相対的に低 密度に抑えた。また，同被覆条件下において，シルバー ポリ及びシルバーストライブフィルムにより土靖表面被 覆した区では，黒色ポりフィルムに比べ1月及び2月の 発生量は少なかったが，3月以降は逆にやや多い傾向を 示した。

また，農業用被覆資材の組み合わせ別の調査围場の内， 要防除密度に基づき当面の防除が必要とされた圃場（60 花当り10頭以上）の比率は，農業用酢酸ビニルもしくは 塩化ビニルフィルム外張り被覆及び黒色ポリフィルムで 土壤表面被覆した固場では，3月以降50\%以上に達した のに対して，シルバーポリもしくはシルバーストライプ フィルムを利用した圈場では，この比率が，相対的に低 く，さらに近紫外線除去ビニル被覆した煵場の内，要防 除密度以上に達した固場の比率は, 各月とも20\%前後で 推移した。

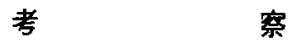

本種が難防除害虫にあげられる原因としては，有効な 登録薬剤が少なく，その安全使用回数が制限されている ため，薬蝺散布のみに依存した防除体系を実施した場合， 生育中後期の被害回避が困難に落ち入る围場が多いこと があげられる。

県内の主要ピーマン産地に，永井ら（1982）により報 告された近紫外線除去フィルムの実証展示围場を設置し 調査を行った。

同一時期に薬剂散布を行った読谷村の実証展示煵場に おいては，近紫外楾除去フィルム区の方が農業用酷酸ビ ニル区よりも本種の生息数，被害果率が共に少なかった が, 従来の肥培管理条件で栽培したため, 近紫外線除去 フィルム区で徒長がみられたり，5月出荷の果奏につや なし果が観察された。

2 年目においても，近紫外線除去フィルムの利用によ り，本種の発生を抑え，薬剤散布回数を 7 回から 2 回に 軽滅することができた。この年は，著しい徒長及びつゃ なし果の発生は観察されなかった。この原因としては， 2 年目に窒素源を押えた肥培管理が実施されたこと，ま た気象条件においても 1 年目は，暖冬により温度（特に 夜温）が平年より高かったため果奏の肥大が早すぎ着色 不足があったのに対し，2年目は低温条件が続いたため 果実の肥大が鈍化したことなどが考えられる。

園芸支場においても，近紫外線除去フィルムの利用に より，本種の生息密度が，塩化ビニル区に比べ抑えられ， かつ，この場合は，果色の差がほとんど認められなかっ た。以上の結果から, 1984年以降県外出荷用ピーマンに 
おいても近紫外線除去フィルムの利用が許可され，読谷 村及び名護市幸嘉の大型ピーマン団地を中心に導入され 始めた。今後の課題としては，さらに，近紫外線除去フ イルムをはじめとする物理的防除法を現場に普及し，要 防除密度に基づく薬剤散布適否の指導を強化する必要が ある。また，本種に对する近紫外線除去フィルムの作用 機作についても検討を加え，ピーマンの生育及び果色に 影響を与えない外張り被覆資材を開発することが必要で ある。

\section{引用 文 献}

1) Iwao, S. (1968) Res. Popul. Ecol. $10: 1-20$ 2) Iwao, S. (1975) Res. Popul. Ecol. $16: 281-288$. 3) Kuno, E. (1969) Res. Popul. Ecol. $11: 127-136$. 4) 永井清文. 野中耕次 (1982) 植物防疫 $36: 466-468$.

(1985年 5 月 11日 受領) 